\title{
THE ROLE OF TRUST IN STUDENT PERCEPTIONS OF UNIVERSITY SEXUAL ASSAULT POLICIES AND SERVICES
}

\author{
OLGA MARQUES \\ ONTARIO TECH UNIVERSITY
}

\author{
TYLER J. FREDERICK \\ ONTARIO TECH UNIVERSITY
}

\author{
HANNAH SCOTT \\ ONTARIO TECH UNIVERSITY
}

\begin{abstract}
Many post-secondary institutions are developing policies and programs aimed at improving responses to sexual assault experienced by students. In some areas, such as Ontario, Canada, the government has mandated post-secondary institutions to do so. However significant these initiatives, they are predicated on the assumption that students trust, and want to engage with, the university following sexual violence. This study explores students' perceptions of sexual assault policies and services on one mid-size university campus focusing specifically on how trust factors into reporting sexual victimization and using services. Findings show that students believe that sexual assault policies and programs exist, but this does not mean students are willing to use such resources or that they even trust that their university has students' needs and interests at the fore. This paper discusses policy and programmatic considerations for building student trust in their post-secondary institutions to encourage student use of campus support.

Keywords: sexual assault policies, student trust, institutional betrayal, sexual violence, university policy, violence prevention
\end{abstract}

\section{Résumé}

Beaucoup d'établissements postsecondaires conçoivent des politiques et programmes visant l'amélioration de leur réponse aux agressions sexuelles vécues par les étudiants. Dans certains lieux, comme en Ontario, au Canada, le gouvernement a obligé les établissements postsecondaires à le faire. Quelle que soit l'importance des initiatives, elles impliquent que les étudiants ont confiance en l'université et qu'ils veulent s'engager avec elle après avoir subi de la violence sexuelle. Cette étude examine les perceptions, parmi les étudiants du campus d'une université de taille moyenne, quant à la politique et aux services en matière de violence sexuelle. Elle se concentre spécifiquement sur le rôle de la confiance dans le signalement de la violence sexuelle et dans l'utilisation des services. La conclusion est que les étudiants croient que des politiques et des programmes en matière d'agression sexuelle existent, mais que cela ne veut pas dire qu'ils sont prêts à utiliser ces ressources ou même qu'ils ont confiance que leur université met les besoins et les intérêts des étudiants au premier plan. Cette étude aborde la politique et les considérations pragmatiques pour l'amélioration de la confiance des étudiants dans leur établissement postsecondaire afin d'encourager le recours à l'assistance du campus parmi les étudiants.

Mots-clés : politiques d'agression sexuelle, confiance des étudiants, trahison institutionnelle, violence sexuelle, politique universitaire, prévention de la violence

\section{Introduction}

Universities are a unique context to examine the issue of sexual violence. One reason is the paradox behind the image of the university as a safe space for students, and the reality that women in post-secondary institutions are at greater risk for sexual assault than women in the general population (Fisher et al., 2000). For many students, the university experience is closely associated with substance consumption, riskier sexual and dating behaviour, and partying (Armstrong et al., 2006; Franklin, 2010), as well as organized social groups (Armstrong et al., 2006). This common university experience is problematic when we consider that most sexual assaults take place at a party (Krebs et al., 2007), after social events, or on dates (Walsh et al., 2010). Research also suggests that some policies and/or practices in place in colleges and universities, seemingly to protect students, heighten 
sexual danger. For instance, bans on alcohol within residences, quiet times, and restrictions on type of social activities that can occur on campus, may lead to increased motivations for riskier off-campus partying, as well as clandestine alcohol consumption in hidden spaces, bars, or unknown residences (Armstrong et al., 2006).

There exists general consensus that sexual violence is a serious problem for women, especially women aged 16 to 24 , who are in college or university (Fisher et al., 2003; Gross et al., 2006; Russell, 1982; Sampson, 2002; Ward et al., 1991). Previous studies assessing prevalence of sexual victimization on campuses estimate that 20-25\% of women experience an attempted and/or completed sexual assault, as legally defined (DeKeseredy \& Kelly, 1993; Fisher et al., 2000; Koss et al., 1987; Krebs et al., 2009). And this problem is showing no signs of disappearing. Indeed, research demonstrates that rates of sexual violence (across the spectrum from unwanted touching to unwanted penetrative sex acts) across college and university campuses have remained relatively stable over the past 30 years (Banyard et al., 2005; Rozee \& Koss, 2001). This is despite the implementation of proactive (prevention programs) and reactive (response resources) efforts during the same time frame (Armstrong et al., 2006). These rates along with a number of high profile incidents occurring on Canadian and U.S. post-secondary campuses, as well as continued victim advocacy have put a spotlight on campus sexual violence.

In response to increasing attention, governments across Canada have mandated that post-secondary institutions develop policies meant to prevent and improve responses to sexual violence on campus. For instance, Bill 132: Sexual Violence and Harassment Action Plan (Government of Ontario, 2015) mandates that all Ontario post-secondary institutions create and adopt sexual violence policies. While Ontario is the first province in Canada to demonstrate broad-scale commitment towards the prevention of, and systemic change surrounding, sexual violence in post-secondary institutions, other provinces have taken similar initiatives.

There have been a number of promising developments in response to sexual violence across universities in Canada. Common policy changes include hiring coordinators to oversee the response to sexual violence on campus, increasing education on what constitutes sexual violence and on available services, creating a single point of contact for victims, streamlining and expanding service options, and creating a victim-led reporting pro- cess. The implementation of such initiatives, however, does not mean students will make use of them (Allen et al., 2015; Walsh et al., 2010). While these policies are important, they are premised on the assumption that students trust the university and want to engage with the university following an experience of sexual violence. Low reporting rates of sexual assault in general (DeKeseredy et al., 1993; Fisher \& Cullen, 1999; Fisher et al., 2003), and on campuses specifically (Orchowski et al., 2009; Sable et al., 2006) suggest that such trust may be low or non-existent.

While there exists literature on barriers to sexual assault disclosure as well as on students' perceptions of sexual assault on campus, research on students' perceptions, understandings, and knowledge of campus sexual assault policies and/or services (Garcia et al., 2012; Mancini et al., 2016; Nasta et al., 2005; Streng \& Kamimura, 2017), particularly as it relates to sexual violence on Canadian campuses, is limited (Council of Ontario Universities, 2020; Quinlan et al., 2016). Students' opinions of campus adjudication of sexual assault, and students' likelihood of reporting sexual assault to campus authorities, also remains largely unexplored (Amar et al., 2014; Orchowski et al., 2009; Taylor \& Gassner, 2010). This is significant as students' perceptions of campus sexual violence resources may affect their willingness to report (Garcia et al., 2012). There is also little research that explicitly considers the role of trust in students' decisions to disclose victimization to the university/college and use their provided resources.

The notion of trust is particularly important given that universities-through the implementation of reporting-related policies and practices-implicitly position themselves as spaces that students would, or even should, turn to after experiencing sexual victimization. Thus, the purpose of this paper is to examine students' awareness and perceptions of campus sexual violence policies and resources, as well as whether or not they would use such resources and why. Emphasizing the voices of students, this paper explores the often-neglected issue of how lack of trust may be a barrier to reporting and utilizing services post-victimization. This paper examines how students talk about trust-drawing attention to the discourses students use as well as the factors that influence feelings of trust among students. By identifying where some students' lack of trust stems, post-secondary institutions can take steps to address those concerns. 


\section{Institutional Betrayal}

Sexual assault continues to be one of the least reported crimes. In Canada, for every 100 sexual assaults, less than 1 per cent of accused are actually convicted (Department of Justice Canada, 2017). As part of a 20-month long investigation, the Globe and Mail's investigative series Unfounded, found that police dismiss 1 in 5 sexual assault claims as baseless. This has resulted in a national unfounded rate in Canada of $19.39 \%$, higher than any other type of crime (Doolittle, 2017). Having concerns related to how the case will be handled in the criminal justice system is one reason survivors cited for not reporting sexual assault victimization, suggesting that victims lack faith and/or trust in police, with respect to reporting, and the system overall (Cotter \& Conroy, 2017). The potential for re-victimization of survivors by the police and courts, has been described as "distressing, demeaning, and humiliating" (Zydervelt et al., 2017, p. 551). It is another source of trauma in addition to the act of sexual violence, but at the hands of the criminal justice apparatus, or institution.

Institutional betrayal occurs when an institution causes harm to an individual who trusts or depends on that institution (Smith \& Freyd, 2014). Institutions elicit similar trust and dependency found in interpersonal relationships (Smith \& Freyd, 2014). This means that individuals can feel that they have been betrayed by an institution, just as they can by another individual (Smith \& Freyd, 2014). For instance, institutional betrayal can include realities such as: police officers dismissing sexual assault allegations as unfounded, investigators and lawyers engaging in what is perceived as victim-blaming interrogation strategies, and experiencing re-victimization and/or secondary trauma after formally reporting sexual violence (Cotter \& Conroy, 2017)-all of which can lead to an overall lack of trust in the criminal justice system. The emotional, psychological, behavioural, and social impacts of a traumatic experience leaves victims with many needs; this trauma is amplified when institutions that are posited as both sources of help and justice fail to help or directly cause more harm.

Smith and colleagues (2014) explain that institutional betrayal includes both (a) acts of commission (e.g., covering up information, insensitive/victim-blaming responses to disclosures of trauma, misreporting or not taking reports seriously) and (b) failing to prevent mistreatment (e.g., withholding information and/or services, not communicating to victims all options, insufficient legal protection). As Campbell (2006, p. 703) notes, "When victims reach out for help, they place a great deal of trust in the legal, medical, and mental health systems as they risk disbelief, blame, and refusals of help." As such, institutions such as judicial systems, schools (including post-secondary institutions), and hospitals have the potential to either exacerbate trauma or become sources of support and healing (Campbell, 2006). Institutional betrayal leading up to or following a sexual assault is associated with more posttraumatic symptoms, including depression, PTSD, lower self-esteem, and dissociation (Smith et al., 2014; Smith \& Freyd 2014).

Although institutional betrayal can take many forms, violation of trust is one significant component. This is particularly salient when the institution is one that is touted to be, "safe, inclusive, and accepting", as per the Ontario Ministry of Education website (2020). Inadequate response systems for sexual assault can foster a deep sense of mistrust among students and community members alike (Smith \& Freyd, 2013). Believing that sexual assault disclosures and reports will not be taken seriously or that survivors will not be treated with care and compassion may serve to violate student's trust in the institution, its policies, and its resources (Holland \& Cortina, 2017).

Research from the United States has found that many sexual assault survivors have experienced institutional betrayal (Bordere, 2017). Many student survivors of sexual assault who reported to their post-secondary institutions are filing complaints against their schools for the re-victimization they experienced after reporting (Johnson et al., 2016). Other research has found that universities "are failing to comply with the law and best practices in handling sexual violence on campus" (U.S. Senate, 2014, p. 4).

In Ontario, the recently released Student Voices on Sexual Violence Survey Results (Council of Ontario Universities, 2020) found that $23 \%$ of university students reported a non-consensual sexual experience, with $63.2 \%$ reporting experiencing sexual harassment one or more times. Of the $46 \%$ of university students who disclosed an incident of sexual violence, $97.8 \%$ told a friend, family member, or roommate. Only $9.4 \%$ told a faculty or staff member at their institution, with $22.4 \%$ indicating that they did not know where to find support on campus. These numbers are significant and problematic given that post-secondary institutions across Canada have 
created sexual violence policies as well as practices, procedures, and supports for victims, and awareness campaigns for the institution at large. The university purports itself as a safe space, a space of trust, yet do students experience it this way? That very few victims of sexual violence disclose or report their experiences to their institutions is telling, particularly in light of a recent news media report that "Canadian universities are failing students on sexual assault" (Schwartz, 2018). Institutional betrayal provides the theoretical starting point to understand the lack of reporting by students who have been sexually victimized.

\section{Literature Review}

\section{Barriers to Reporting}

Researchers posit several explanations for sexual assault survivors deciding not to report their victimization, particularly as it relates to college and university-aged women. The main barriers to reporting include: "(1) shame, guilt, embarrassment, not wanting friends and family to know; (2) concerns about confidentiality; and (3) fear of not being believed" (Sable et al., 2006, p. 157). In addition to not reporting due to the personal and potentially embarrassing nature of the crime (Sampson, 2002), since acts of sexual violence may not have resulted in visible physical injuries, victims may not characterize these as "true" sexual assault or rape, and therefore do not report (Fisher et al., 2003; Gross et al., 2006; Sampson, 2002; Ward et al., 1991). Many women also refrain from reporting because they do not think the incident was serious enough (Fisher et al., 2003). This is especially true if the victim knew the perpetrator (Gross et al., 2006; Sampson, 2002; Ward et al., 1991). Moreover, knowing the perpetrator can cause victims to not disclose for fear of reprisal from both the perpetrator and their friends (Sampson, 2002). Disclosure decisions can reflect a rational assessment to not turn in fellow students, which may result in negative consequences for their peer groups but little or no action by the justice system (Fisher et al., 2003). Victims also fail to report because of the social stigma attached to this form of victimization (Fisher et al., 2003; Sampson, 2002) and fear of being blamed (Fisher et al., 2003).

Certain policies put in place to protect students and campus space may have the unintended consequence of discouraging reporting. For instance, some victims of sexual assault may believe that the costs of reporting (e.g., getting in trouble for drinking alcohol) outweigh any possible benefits (Russell, 1982). Since the majority of campus sexual assaults involve drinking and/or substance use by the victim, those who are assaulted while incapacitated may not only fear they will be blamed for their victimization, but that they may also end up receiving sanctions if they report the incident to university officials (Karjane et al., 2005; Ward et al., 1991).

\section{Trust and Confidence in Authorities and Crime Reporting}

Underscoring the barriers to sexual assault reporting is the issue of trust. Trust per se, however, is not a central focus of previous research on sexual assault reporting and disclosure practices among post-secondary students. Research instead typically emphasizes the influence of personal factors (e.g., PTSD, psychological characteristics, gender, race) and factors related to the nature of victimization (e.g., relationship to the victim, presence of alcohol, if there was physical injury). There is less explicit consideration of factors related to the institution, such as general trust in the institution itself.

There is, however, indication that trust is a relevant factor. First, most survivors of sexual violence report their victimization to somebody, just not law enforcement or those in authority. Friends and health professionals are two groups that victims of sexual violence are likely to disclose to (Fisher et al., 2003; Suzuki \& Bonner, 2017). This suggests that victims have more trust in the response from those sources than institutional ones. Second, as previously noted, victims cite fear of not being believed or of being blamed as reasons for not reporting victimization or accessing services (Fisher et al., 2003; Walsh et al., 2010). Third, among studies that do consider institutional factors, there is indication the individuals are more likely to report when they trust the adjudication process and have a favourable attitude to those taking the report (Amar et al., 2014; Fisher et al., 2003; Karjane et al., 2005; Strout et al., 2014). Fourth, research on the reporting of non-sexual violence on campus finds that students with more trust in the university response system (e.g., campus police, administrators) and those with a closer connection to the campus are more likely to 
report potential threats (Sulkowski, 2011).

Related research on reporting sexual violence to the police similarly points to the importance of trust. For example, studies find that those who trust the police are more likely to report, and that women with past victimization experience are the least likely to report, suggesting that negative past experiences have impacted their trust in the process (Orchowski et al., 2009)

Trust in authorities is relevant for understanding the underreporting of sexual victimization on campus, given that young adults hold less favourable views towards the police, resulting in decreased satisfaction in the police and their services (Williams \& Nofziger, 2003). As a whole, college students report lower levels of confidence in the ability of police to handle a major crisis than their non-college counterparts (Williams \& Nofziger, 2003), suggesting that lack of trust may serve as a barrier to reporting.

\section{Methods}

The data for this paper come from a larger research project on campus sexual violence experiences of students, staff, and faculty, funded by the Ontario Ministry of Community Safety and Correctional Services. The study included volunteer respondents with and without a history of campus sexual assault. Data was collected via an indepth mixed methods design that included a 20-minute online survey and in-depth interviews. ${ }^{1}$ The survey was adapted from the Massachusetts Institute of Technology 2014 Community Attitudes on Sexual Assault Survey and Cycle 28 of the Statistics Canada General Social Survey focusing on victimization. The survey was adjusted to focus on particular victimization experiences, evidence of sexual assault supportive culture, and responses to sexual assault experiences. Based on these previous surveys, questions asked respondents about their knowledge and perceptions of sexual assault (e.g., "It is not necessary to get consent before sexual activity if you are in a relationship with that person"). Questions also asked respondents about experiences of specific sexual situations, separating these into wanted or unwanted (e.g., "Someone sexually penetrated me (someone put a penis or inserted fingers or objects into my vagina or anus) even though I didn't want to"). Additional questions focused on reporting practices (whether real or hypothetical) and levels of satisfaction with institutional supports and police responses. This ensured that we had data on whether students had used available services and why, and if they thought they would use the services and why. Two hundred and fifty women participated in the survey.

We also conducted in-depth qualitative interviews to supplement the survey data with more in-depth descriptive information. Interviews focused on how students understand the concepts of sexual violence and harassment, the sources of this knowledge, and how students perceive the campus environment. In total, 15 individual interviews with women were conducted. It is important to note that this study was conducted prior to the mandated implementation of sexual violence policies across Ontario's post-secondary institutions.

We recruited participants for both components of the study through advertisements sent via the university's email system and posters placed around campus. We also asked faculty members to announce the study in their classes. To participate in the survey, interested participants used a link connecting them to a secure online survey. To participate in the interview, participants contacted the researchers using an email address designated to the study. The researchers then scheduled in-person interviews.

Trained and experienced research assistants conducted the interviews to protect students' confidentiality since they could be known to faculty members leading the study. Participants received a $\$ 20$ honorarium for their time. The interviews were conducted in private offices, audio recorded, and transcribed by a secure service provider. The research assistants removed any potentially identifying information from the transcripts prior to distributing them to the larger research team.

For the purposes of this article, with the exception of demographic information and anticipated use of university resources, the data analysis described herein focuses primarily on the qualitative data from both the survey (short answer question) and the individual interviews. Only the data from the women participants is used in this article (survey $=250$ women; individual interviews $=15$ women). The researchers manually coded the data using simultaneous and thematic techniques (Saldaña, 2009). Qualitative analysis of the survey responses focused on a question asking participants why they would/ would not use specific university-provided resources. The qualitative analysis of the interview data focused on the women's discussion of their knowledge of university 
sexual assault and harassment policies and programs, whether they would report sexual assault or harassment to university officials or use any related university-provided services, and why. The first-level coding organized the data according to these specific themes. The second-level coding then identified the more nuanced patterns in the data as identified by the researchers (Elliott, 2018).

\section{Participant Profile}

Two hundred and fifty women $(n=250)$ participated in the online survey. Below, we report the valid percent of responses-i.e., we exclude those who did not respond to the question from the denominator. One hundred and fifty-one participants $(n=151)$ reported their race or ethnicity. The average age of the participants was 21 years and ranged from 18 to 41 years. Approximately $60 \%(n=89)$ of the women who reported their race or ethnicity were White, while $17 \%(n=26)$ were South Asian, $7 \%(n=10)$ were Black, and $17 \%(n=26)$ reported a variety of other racial/ethnic backgrounds. Approximately $87 \%(n=215)$ of the women who participated in the online survey identified as heterosexual while $7 \%(n=16)$ were bisexual, $2 \%(n=6)$ were lesbian, and 4\% ( $n=11)$ reported another sexual orientation. Almost all of the women in the study were undergraduate students $(92 \%, n=228)$. Just under $35 \%(n=67)$ reported having been sexually assaulted while at university.

Fifteen women participated in interviews. The average age of the interview participants was 22 years and ranged from 18 to 46 . Five of the participants identified as Black, four as White, three as South Asian, one as Middle Eastern, and two identified with multiple racial/ ethnic origins.

\section{Findings}

We focus our findings around four central themes: (1) awareness of university policies and procedures related to sexual violence; (2) misplaced trust in the existence of university policies/procedures, (3) awareness and willingness to use university resources and services; and (4) a lack of trust and confidence in university-provided services/resources.

\section{Awareness of University Policies on Sexual Assault and Harassment}

We asked the interview participants to tell us what they knew about the university's policies and procedures on sexual violence and harassment. Of the 15 women interviewed, 11 said they were unaware of the universities policies and procedures. For example, one woman said:

I actually don't know anything about it...I don't know [how] the procedure works or what they do, or the help number...I don't know how they handle it...how they run things...I don't know anything about your policies.

Another woman echoed this sentiment, indicating that the university provided information on safety precautions students should take, but no information on specific policies themselves.

Honestly, I couldn't tell you too much about it. I don't know much because when I read the emails that we do get, it usually says "have a buddy with you at all times or most of the time, especially if it's night or there's not many people on campus." However, I don't remember any policies or rules specifically.

One woman pointed out that even after being at the university for two years, she still did not know the policies in place, saying: "They haven't done one [information session] since [orientation] and I'm, like, in my second year. So, like, no, I didn't even know they had rules."

In addition to a general unawareness of the policies, six of the women interviewed stated that they had no idea where to make such reports. For those who did not know where to report, one woman said:

Yeah, I don't even know where I would go to report, I'd have to find out where the places are on campus for stuff to decide if I even want to report, based on what consequences that come through it. So that would be a barrier and I then have to find out who to take [it] to.

Another woman indicated that while students receive an abundance of information on sexual assault generally, there is less information on where to report. She stated: "You see around school, you see all the awareness about...sexual assault, and whatnot, but you don't really know the how to report it. Like, where do you go?" 


\section{Misplaced Trust in the Existence of University Policies}

While the majority of women interviewed were unaware of the university's policies on sexual harassment and assault, nine out of the 15 women interviewed specifically indicated that they believed or hoped that the university had such policies in place. The women appeared to have misplaced trust and confidence that the university had such policies in place, given that they did not actually know what the specific policies were and that this university did not have separate polices for sexual assault in place at the time of their interviews. Some of the women were quite confident in their belief that such policies existed. For example, one woman said: "I know that there's a zero-tolerance policy for sexual violence."

Other participants' comments suggest faith that the university takes sexual harassment and assault seriously and has appropriate policies. For instance:

I don't know anything specific, but l'm pretty sure it's serious, it's really serious. Like I would—I would think that they would really [take it] seriously, if somebody accused somebody else of sexual harassment.

As another woman stated:

I know that [the university] has a discrimination and harassment policy...but in specifics to sexual violence or harassment I would like to think that-I know some of it does actually pertain to...specifically sexual harassment component to that policy and I think it's just-I know it's not accepted, by any means, and you're protected under the human rights and things like that, so I know [emphasis added] that there is something there.

One woman held her university to a high standard and had faith that her university, in particular, would certainly have such policies.

Yeah, I mean I think that would be a standard at any university, but I feel like [the university name] specifically would do a good job of that. I wouldn't doubt it. Like if something like that were to happen to me, I feel like I would easily be able to find sources here.

This faith in the existence of university policies and procedures surrounding sexual assault is also evident in statements by participants that even though they are unaware of the content of such policies they know they could find the information. Most said they would look online for such information. As one participant indicated:

I'm sure if I looked it up I could find out in a few seconds...I would have to talk to somebody or look it up or something like that... I would probably just Google search it first... And see if there's anything online... And if I wanted to find out further I would try to find out if there's an office or something like that they have and then go in.

Another woman echoed this in her response:

I mean, they have all their stuff on the website. So if I Googled it...and they would probably tell me where to go or at least where to start looking. Because I'm sure they have, like, these resources. If you're close maybe, like...I know my academic advisor so, like, I could ask, like, "Do you know what services are available to students?"...Even if you ask your prof, I'm sure they could direct you in the right way.

These findings point to a lack of knowledge among students of the policies and procedures in place (or not in place) regarding sexual assault and harassment. The data further suggests students expect their universities to have such policies and procedures in place. Given that the survey was conducted prior to the mandate that all Ontario post-secondary institutions have sexual violence policies, this expectation was likely confounded by the widespread discussions that were occurring during this time. This misplaced faith may exacerbate the difficulties women experience after reporting a sexual assault or harassment because of their expectations for clear policies and procedures. These expectations and faith have the potential to heighten women's disappointment if/when the university mishandles sexual assault and harassment cases, which is all too common (Bohmer \& Parrot, 1993).

\section{Awareness and Willingness to Use University Resources and Services}

Although some students are not very well informed about the policies and where to report, the interview participants had greater awareness of campus resources and 
services. Eleven of the 15 women interviewed indicated that they knew of and were able to name resources and services available on campus, such as the health centre, mental health specialists/counsellors, and Outreach Services. Even when students were unaware of the policies and campus resources and services, almost all participants interviewed (13 out of 15) indicated they knew where to find that information. Most said they would look online for such information.

Awareness of university-provided resources, however, does not necessarily mean students would use those services. We asked survey participants whether they would use a variety of university-provided services if they were sexually assaulted in the future. With a few exceptions, the majority of the participants said they would not use or were unsure whether they would use a variety of university-provided services or simply did not know enough about the service to say (see Table 1 for responses for each service/resource).

The data presented in Table 1 represents the university-provided services and resources that survey participants indicated they assumed that they would use should they experience campus sexual violence. While many students indicated that they would not seek out official administrative services/supports (e.g., residence life staff, Ombudsman's office, dean's office), we do see a high proportion of students who indicated they would go to Campus Mental Health Services as well as Campus Health Centres. In addition, many students also en- visioned that they would report the sexual violence to Campus Security. While we cannot, using the data from this study, ascertain whether students would actually use campus security services, existing research indicates women who have experienced sexual violence are unlikely to report to law enforcement (Orchowski et al., 2009).

\section{Lack of Trust and Confidence in University-Provided Services/Resources}

We asked survey participants to explain their responses about which resources they would or would not use. Sixty-eight of the 250 women who participated in the online survey provided a response to this question. In addition, a thematic analysis of these responses revealed that 13 of the 15 women interviewed lacked trust or confidence in university-provided resources. Although we did not ask the interviewees to identify which specific services they hypothetically would or would not use and why in the interviews, participants spoke to the university resources they thought they would not seek out. One woman indicated that-in particular-she does not trust campus security. She said:

Like going to security, no you don't want them to know... sometimes I don't trust the security, I don't know why...Sometimes I feel like they would abuse people, because they're security, they have the pow-

Table 1. Expected Use of University-Provided Services/Resources

\begin{tabular}{|l|l|l|l|l|}
\hline & No & $\begin{array}{l}\text { Unsure/Do not } \\
\text { know enough }\end{array}$ & Yes & Total \\
\hline $\begin{array}{l}\text { Student Association Outreach Ser- } \\
\text { vices }\end{array}$ & $24 \%(n=36)$ & $44 \%(n=66)$ & $33 \%(n=49)$ & $100 \%(n=151)$ \\
\hline Campus Health Centre & $27 \%(n=41)$ & $18 \%(n=27)$ & $56 \%(n=85)$ & $100 \%(n=153)$ \\
\hline Campus Mental Health Services & $23 \%(n=35)$ & $15 \%(n=22)$ & $63 \%(n=95)$ & $100 \%(n=152)$ \\
\hline Student Support Services & $31 \%(n=45)$ & $32 \%(n=46)$ & $38 \%(n=55)$ & $100 \%(n=146)$ \\
\hline Residential Life Staff & $65 \%(n=94)$ & $27 \%(n=39)$ & $8 \%(n=12)$ & $100 \%(n=145)$ \\
\hline The Ombudsman's Office & $43 \%(n=63)$ & $52 \%(n=76)$ & $5 \%(n=7)$ & $100 \%(n=146)$ \\
\hline Student Lifeline & $35 \%(n=51)$ & $40 \%(n=58)$ & $26 \%(n=38)$ & $100 \%(n=147)$ \\
\hline Office of the Dean & $48 \%(n=71)$ & $27 \%(n=40)$ & $25 \%(n=37)$ & $100 \%(n=148)$ \\
\hline Campus Security & $31 \%(n=46)$ & $13 \%(n=20)$ & $56 \%(n=83)$ & $100 \%(n=149)$ \\
\hline
\end{tabular}


er, you want to feel safe with them but maybe they will abuse you or like, rape you or something.

This lack of trust in the university's abilities to handle sexual assault and harassment is also evident in another woman's recommendation for police involvement when assault is reported.

I think it should be dealt with internally and with the help of the police services...Again, situational, but if like a student didn't report it and they [the university] found [out]-they got knowledge of it they should deal with it within their policies. But then if there needs to be any legal ramifications then I think the police should be brought in...depending on what's going on, what happened, who the victim was, who the assailant was, were they a student, just things to consider within-like whether that's within their scope or if it needs to be brought to bigger peoples to get involved...I think for sure the police...police is [the] main thing...I don't think they're [the university] going to do a whole lot [emphasis added]... I think anything, even harassment, I would think if it-if it was like just one comment then it's kind of the school could probably deal with that, but if it's continuous comments, they were told to stop, the school might have to bring it to higher authorities to deal with it, but anything beyond multiple comments like unconsented touching, anything like that, that should be the police.

Similarly, a student echoed this lack of confidence, stating: "I don't feel that school services will help, I think going straight to the police would be better."

Another student explained that her experiences with campus mental health services led to her lack of confidence in this particular service's ability to provide care to victims.

I've talked to counsellors before-at the line up to get in, it's crazy the amount of paperwork you have to go through. It doesn't feel confidential. It doesn't feel personal. It doesn't feel genuine... There's no real solid mental health help on campus. There's too high a volume [emphasis added] of kids and too many varying problems, you know, that the mental things that come with having sexual assault and sexual harassment should be taken care of separately from the kids that are having problems at school, from the kids that are having problems with eating...you know, different therapists for all these kids. It's just not set up well... Just not having enough people in general. Students know that so they don't report anything. They don't want to go talk because it just takes too long and I think they're overworked and they stare at you like they don't really care [emphasis added]. They don't have time, right... And having to walk in every day, there's a stigma around it. It's like a walk of shame almost having to constantly repeat and repeat and repeat exactly what happened over and over again, I think it becomes quite tedious and just not worth it because what is the results, right?

Previous negative experiences informed another student's lack of trust in campus services:

I have had some negative personal experiences with the SA [Student Association] and mental health services at campus health. Therefore, I would not choose to use these services again.

One woman also indicated that she does not trust that the university would have the best interests of victims in mind. She explained:

I don't think that there's any consequences really. Like obviously again there would be in an extreme case, but I mean the violation you have to go through to get your case heard is just absurd...And l've been through the process with a friend of mine...So it's like there wasn't any real support and I mean you see that all over the place. You see even with the incident at like the University of Ottawa with like the men's hockey team. Like, they like to hush that kind of stuff up. Like the university, the police even said-they're like... this isn't really a big enough deal to take to anybody. Like the university wouldn't. They're like, what would they do?... We've got a pretty strong social justice course so l'd like to think that maybe they'd be good about it, but at the same time universities don't like negative publicity [emphasis added] and you see it with the Dalhousie case with the dental group. The victims were-like, you're ruining their-like we're not going to publish them. They didn't even expel them, right? Because that could ruin somebody's future... Yeah. I think a lot of time the victim gets told to be quiet... It's [the university] a business [emphasis added]. 
I mean people donate money to it, right? It's a public image thing. Who wants [university name] rape victim like splayed across national headlines, right?... think that's related to it getting wrote off.

A survey participant similarly voiced a lack of trust that the university would prioritize students over their reputation. She stated:

I would look towards community/law enforcement assistance before campus. I do not trust that campus administration would take me as seriously as community or law enforcement, as [the] campus has a reputation stake to consider [emphasis added].

This lack of trust in the university prioritizing victims is also evident in one woman's call for universities to better support victims and for an advocate or counsellor to be present when a victim is reporting. Recommending an advocate or counsellor be present suggests that this student thinks that victims need someone to advocate for them when interacting with the university; the university will not be their advocate. She said:

I think we need to make a process where not assuming guilt, but believing that what the victim is saying is like their truth, you know what I mean? There needs to be more support and I think-l'm not sure how the-how it goes now when you report a thing, but I think there should always be a counsellor present, like someone to kind of-like there should be a counsellor or an advocate for the victim to make sure that they don't get ... Like the big thing is like, people trap you. Like they'll-if you make one mistake in a story from one telling to the next they like to trap you and say that like oh, well, they lied, they must have lied about everything, whereas like, victim recall is bad, right? It's always bad. And so it's one of those things where I think that like, bringing in an advocate for them to like, help them, right, and to make sure that they're not just bullied into dropping the charges. And as much as universities like, aren't supposed towouldn't-you'd like to think they would never want you to be quiet about it, like someone to ensure that they're not just getting, you know, hushed up about the incident

For some students, their lack of trust in the university is justified based on past experiences. One participant reported that the university responded with concern for the offender when she reported an incident:

[The person she contacted] told me to think about the consequences for the offender, and how what happened wasn't important enough for them to get in the kind of trouble that they would.

Another participant specified that her experiences after reporting did not demonstrate the university services' ability to adequately support victims. She said:

[The person she contacted] tried and continues to try convince you to be happy, smile, cheer up. I find this is like telling someone with a bad headache to just stop having a headache; it doesn't work like that. It affects everything you do... cannot study, cannot go out, don't want to get changed, and just want to sleep it off and hope the "headache" is gone tomorrow.

The lack of trust and confidence also stem from concerns about confidentiality and who are providing the services, as some campus services allow students to volunteer or work within them. Three participants stated:

Since [the university] is so small I would prefer to use outside agencies that aren't staffed by students. I know a lot of people who work for the student association. I wouldn't feel comfortable with them knowing all this about me.

I wouldn't want anyone in the school to know, especially if there are students working in those centres. People talk.

[The university is] too small for anonymous treatment. I have severe distrust in [the university] and student association services based on a previous situation.

Another participant expressed a general concern that using campus services would be connected to her throughout her time at the university.

I believe I would not want to use school services, because it would be attached. Like that's will be connected with everything I do after.

These results highlight that some students do not have trust in the institution or its resources and services. 
Perceptions of the university and prior experiences can cause students to question the confidentiality, intentions, abilities, and effectiveness of the university and its response to sexual violence. As such, students may not take advantage of university-implemented policies and resources-sometimes for justifiable reasons.

\section{Discussion}

The underreporting of campus sexual violence should concern college and university administrators as choosing not to report can: (a) preclude the apprehension of alleged perpetrator(s); (b) impede the victims access to, or even knowledge of, potential services and resources; but also (c) may serve to create an overall climate of distrust and overall lack of confidence that campuses are safe spaces. Previous research suggests that students want more education about sexual violence and campus resources (Garcia et al., 2012), while simultaneously highlighting that current university prevention education and programming are ineffective in reducing campus sexual assault (Anderson \& Whiston, 2005; Kress et al., 2006). One reason may be because victims tend to disclose to friends rather than authorities (Fisher et al., 2003). Our research suggests that many students do not trust that university services are effective, confidential, or that the university would even prioritize victims over institutional interest. While this corresponds to previous research that identifies feelings such as shame, guilt, and embarrassment, concerns about confidentiality, and/or not wanting others to find out (Sable et al., 2006) as barriers to reporting of sexual violence, it is concerning that students feel this way about the university they attend and further research should delve deeper into this issue. For instance, future research should attend to why students perceive that their college or university would prioritize institutional over student interest, and what experiences have led them to perceive a lack of confidentiality or effectiveness of support services. These issues are important given that Smith and Freyd (2014) highlight that institutional betrayal adds another layer of trauma that sexual violence victims may face.

Betrayal trauma is not only caused by trusted caregivers, friends, or family members, but also by trusted institutions, or institutions that individuals are in a situation to depend upon, such as the legal and education system (Smith \& Freyd, 2014). When individuals are dependent upon an institution, in this case a university, institutional betrayal occurs when that institution fails to either prevent harm or to respond supportively and effectively to victims who have been harmed within the context of that institution (Smith \& Freyd, 2013). While our findings do not explicitly speak to instances of institutional betrayal, they do suggest that students simultaneously have belief that proper policies, procedures, and supports exist (even though they did not at the university in this study at the time the research was conducted), but do not actually trust the university as a place where they would want to seek out these services.

Establishing and sustaining trust is, therefore, a key challenge for post-secondary institutions as they move forward in supporting victims of campus sexual assault as well as fulfilling mandates to develop or revise sexual violence policies and services. The question to remain at the fore is: Why should a victim report to the university and use their resources? That is, what makes the university perceptually or functionally different from other institutions such that students would choose to disclose acts of sexual violence to the university? As our findings suggest, while some students believe that policies and resources related to sexual violence exist on campus, a lack of trust can-at best-hinder and-at worst-prevent students from disclosing victimization to universities and from using university-provided services. While previous research attends to reasons why victims choose to report-or not to report-acts of sexual violence perpetrated against them, attending to those reasons within a framework of trust is limited. Focusing on police reform, but applicable here, Goldsmith (2005, p. 464) argues that "[e]xplicating the "problem of trust' is central," highlighting that: "we need to discover more about the forms of public distrust of police and in particular the co-existence of areas of trustfulness and distrustfulness towards police within the one individual or community." Given the amount of attention, effort, and resources post-secondary institutions are putting towards policies, practices, and services, it is important that further research is done to explore how students perceive the trustworthiness of the university. This is especially significant if we expect students to use the campus as an avenue of disclosure, redress, and support.

We argue that it is important for colleges and universities to foster good relationships between students and its police/security-as well as other services-in 
order to build trust. Campuses are communities unto themselves. By fostering and maintaining these relationships, students may not only feel safer in this community, but may also develop trust in university disclosure and adjudication processes, as well as in the services they offer. The implementation of coordinated and holistic responses, such as Sexual Assault Response Teams (SART) (Nugent-Borakove et al., 2006), may also serve to cultivate trust in students. SARTs draw from law enforcement/security, healthcare, women's centres, victims' advocates, counselling, and legal aid with the goal of increasing reporting, assisting sexual assault victims with recovery through support, and facilitating communication between all parties involved in the disclosure, investigation, and adjudication of the assault through to (if desired) the criminal justice system. Preliminary findings evaluating such initiatives are positive, suggesting that they serve to instill confidence in police, increase reporting, and establish a track-record of successful assistance and support (Nugent-Borakove et al., 2006). While some communities are starting to use such formalized and coordinated team responses in collaboration with local police services, implementing similar coordinated response teams on campus merits some consideration and future study.

An important consideration is that colleges and universities also need to be seen as deserving of trust, and not to automatically assume institutional trust exists. If students believe, as our findings suggest, that an institution's reputation will be prioritized over student concerns, trust will not exist. A policy consideration offered here to campus administrators is to grant immunity to victims of sexual assault. Student codes of conduct are common for colleges and universities, and can cover myriad behaviours, including prohibitions against alcohol use in campus residences. Depending on the conduct policy, charges can be filed against students for misconduct, even if this misconduct occurred off campus, as long as they were representing themselves as current students. Sanctions range from warnings or probation to expulsion from the post-secondary institution. Victims, especially those who have engaged in (underage) drinking may not come forward and report to campus security for fear of punishment. Information concerning this immunity should be clear in official sexual violence policies. Offering this immunity to judicial charges to victims of crimes may improve students' institutional trust. Post-second- ary institutions, in addition to improving institutional responses to sexual violence, must also seek to demonstrate integrity in those responses to ensure that victims have more effective modes of reporting that will serve to truly enhance campus safety for all students.

\section{References}

Allen, C. T., Ridgeway, R., \& Swan, S. C. (2015). College students' beliefs regarding help seeking for male and female sexual assault survivors: Even less support for male survivors. Journal of Aggression, Maltreatment \& Trauma, 24(1), 102-115. https://doi. org/10.1080/10926771.2015.982237

Amar, A. F., Strout, T. D., Simpson, S., Cardiello, M., \& Beckford, S. (2014). Administrators' perceptions of college campus protocols, response, and student prevention efforts for sexual assault. Violence and Victims, 29(4), 579-593. https://doi. org/10.1891/0886-6708.vv-d-12-00154

Anderson, L. A., \& Whiston, S. C. (2005). Sexual assault education programs: A meta-analytic examination of their effectiveness. Psychology of Women Quarterly, 29, 374-388. https://doi.org/10.1111/j.14716402.2005.00237.x

Armstrong, E. A., Hamilton, L., \& Sweeney, B. (2006). Sexual assault on campus: A multilevel, integrative approach to party rape. Social Problems, 53(4), 483-499. https://doi.org/10.1525/sp.2006.53.4.483

Banyard, V. L., Plante, E., Ward, S., Cohn, E. S., Moorhead, C., \& Walsh, W. (2005). Revisiting unwanted sexual experiences on campus: A 12 year follow-up. Violence Against Women, 11(4), 426-446. https:Il doi.org/10.1177/1077801204274388

Bohmer, C., \& Parrot, A. (1993). Sexual assault on campus: The problem and the solution. Lexington Books.

Bordere, T. (2017). Disenfranchisement and ambiguity in the face of loss: The suffocated grief of sexual assault survivors. Family Relations, 66(1), 1-17. https://doi.org/10.1111/fare.12231

Campbell, R. (2006). The psychological impact of rape victims' experiences with the legal, medical, and mental health systems. In D. A. Sisti, A. L. Caplan, 
\& H. Rimon-Greenspan (Eds.), Applied ethics in mental health care: An interdisciplinary reader ( $\mathrm{pp}$. 149-177). MIT Press.

Cotter, A., \& Conroy, S. (2017). Self-reported sexual assault in Canada, 2014. Statistics Canada. https:/l www150.statcan.gc.ca/n1/pub/85-002-x/2017001/ article/14842-eng.htm

Council of Ontario Universities. (2020). Student voices on sexual violence climate survey. https://ontariosuniversities.ca/student-voices-on-sexual-violence-survey

DeKeseredy, W., \& Kelly, K. (1993). The incidence and prevalence of woman abuse in Canadian university and college dating relationships. Canadian Journal of Sociology, 18(2), 137-159. https://doi. org/ $/ 10.2307 / 3341255$

DeKeseredy, W., Schwarts, M. D., \& Tait, K. (1993). Sexual abuse in Canadian university and college dating relationships: The contribution of male peer support. Journal of Family Violence, 10(1), 41-53. https://doi. org/10.1007/BF02110536

Department of Justice Canada. (2017). Knowledge exchange on the criminal justice system's response to sexual assault against adults. Author. https://www. justice.gc.ca/eng/cj-jp/victims-victimes/cal/summ-resu.html

Doolittle, R. (2017, February 3). Why police dismiss 1 in 5 sexual assault claims as baseless. Globe and Mail. https://www.theglobeandmail.com/news/investigations/unfounded-sexual-assault-canada-main/ article33891309/

Elliott, V. (2018). Thinking about the coding process in qualitative data analysis. The Qualitative Report, 23(11), 2850-2861. https://nsuworks.nova.edu/tarl vol23/iss11/14l

Fisher, B. S., Cullen, F. T., \& Turner, M. G. (2000). The sexual victimization of college women: Research report. Department of Justice, Washington DC. National Institute of Justice.

Fisher, B. S., Daigle, L. E., Cullen, F. T., \& Turner, M. G. (2003). Reporting sexual victimization to the police and others: Results from a national-level study of college women. Criminal
Justice and Behaviour, 30(1), 6-38. https://doi. org/10.1177/0093854802239161

Fisher, B. S., \& Cullen, F. T. (1999). Extent and nature of the sexual victimization of college women: A national-level analysis. Department of Justice, Bureau of Justice Statistics. https://www.ncjrs.gov/pdffiles1/nij/ grants/179977.pdf

Fisher, B. S., \& Cullen, F. T. (2000). Measuring the sexual victimization of women: Evolution, current controversies, and future research. Criminal Justice, 4, 317-390. https://www.publicsafety.gc.ca/lbrr/archives/cnmcs-plcng/cn34984-v4-317-390-eng.pdf

Franklin, C. A. (2010). The effect of victim attitudes and behaviours on sexual assault victimization severity: An examination of university women. Women and Criminal Justice, 20(3), 239-262. https://doi.org/10. 1080/08974454.2010.490479

Garcia, C. M., Lechner, K. E., Frerich, E. A., Lust, K. A., \& Eisenberg, M. E. (2012). Preventing sexual violence instead of just responding to it: Students' perceptions of sexual violence resources on campus. Journal of Forensic Nurses, 8(2), 61-71. https:ll doi.org/10.1111/j.1939-3938.2011.01130.x

Goldsmith, A. (2005). Police reform and the problem of trust. Theoretical Criminology, 9(4), 443-470. https://doi.org/10.1177/1362480605057727

Government of Ontario. (2015). It's never okay: An action plan to stop sexual violence and harassment. http://docs.files.ontario.ca/documents/4136/mi2003-svhap-report-en-for-tagging-final-2-up-s.pdf

Gross, A., Winslett, A., Roberts, M., \& Gohm, C. (2006). An examination of sexual violence against college women. Violence Against Women, 12(3), 288-300. https://doi.org/10.1177/1077801205277358

Holland, K. J., \& Cortina, L. M. (2017). The evolving landscape of title IX: Predicting mandatory reporters' responses to sexual assault disclosures. Law and Human Behaviour, 41(5), 429-439. https://doi. org/10.1037//hb0000253

Johnson, A., Butcher, M., Thomas, K. H., Jemsek, J., \& Sheilds, M. M. (2016). Stopping sexual assault on private college campuses: Impact evaluation of a prevention and awareness intervention conducted 
with community partners at a Christian university. Journal of Health Education Teaching, 7(1), 23-31. https://files.eric.ed.gov/fulltext/EJ1113040.pdf

Karjane, H., Fisher, B., \& Cullen, F. (2005). Sexual assault on campus: What colleges and universities are doing about it. U.S. Department of Justice, National Institute of Justice.

Koss, M. P., Gidycz, C. A., \& Wisniewski, N. (1987). The scope of rape: Incidence and prevalence of sexual aggression and victimization in a national sample of higher education students. Journal of Consulting and Clinical Psychology, 55(2), 162-170. https://doi. org/10.1037//0022-006x.55.2.162

Krebs, C. P., Lindquist, C. H., Warner, T. D., Fisher, B. S. \& Martin, S. L. (2007). The campus sexual assault (CSA) Survey. https://www.ncjrs.gov/pdffiles1/niil/ grants/221153.pdf

Krebs, C. P., Lindquist, C. H., Warner, T. D., Fisher, B. S., \& Martin, S. L. (2009). College women's experiences with physically forced, alcohol- or drug-enabled, and drug-facilitated sexual assault before and since entering college. Journal of American College Health, 57(6), 639-647. https://doi.org/10.3200/ JACH.57.6.639-649

Kress, V. E., Shepard, B. J., Anderson, R. I., Petuch, A. J., Nolan, J. M., \& Thiemeke, D. (2006). Evaluation of the impact of a coeducational sexual assault prevention program on college students' rape myth attitudes. Journal of College Counseling, 9, 148-157. https://doi.org/10.1002/j.2161-1882.2006.tb00101.x

Mancini, C., Pickett, J. T., Call, C., \& Roche, S. P. (2016). Mandatory reporting (MR) in higher education: College students' perceptions of laws designed to reduce campus sexual assault. Criminal Justice Review, 41(2), 219-235. https://doi. org/10.1177/0734016816634787

Massachusetts Institute of Technology. (2014). Community attitudes on sexual assault survey. https:/l chancellor.mit.edu/sites/default/files/pdf/MITCommunityAttitudesonSexualAssault-Survey.pdf

Nasta, A., Shah, B., Brahmanandam, S., Richman, K., Wittels, K., Allsworth, J., \& Boardman, L. (2005). Sexual victimization: Incidence, knowledge and resource use among a population of college women. Journal of Pediatric Adolescent Gynecology, 18(2), 91-96. https://doi.org/10.1016/j.jpag.2005.01.002

Nugent-Borakove, M. E., Fanflik, P., Troutman, D., Johnson, N., Burgess, A., \& O'Connor, A. L. (2006). Testing the efficacy of SANE/SART programs: Do they make a difference in sexual assault arrest and prosecution outcomes? American Prosecutors Research Institute.

Ontario Ministry of Education. (2020). A safe and welcoming school environment. http://www.edu.gov. on.ca/eng/parents/safeschools.html

Orchowski, L. M., Meyer, D. H., \& Gidycz, C. A. (2009). College women's likelihood to report unwanted sexual experiences to campus agencies: Trends and correlates. Journal of Aggression, Maltreatment and Trauma, 18, 839-858. https://doi. org/10.1080/10926770903291779

Quinlan, E., Clarke, A., \& Miller, N. (2016). Enhancing care and advocacy for sexual assault survivors on Canadian campuses. Canadian Journal of Higher Education, 46(2), 40-54. https://files.eric.ed.gov/ fulltext/EJ1113446.pdf

Rozee, P. D., \& Koss, M. P. (2001). Rape: A century of resistance. Psychology of Women Quarterly, 25, 295-311. https://doi.org/10.1111/1471-6402.00030

Russell, D. (1982). The prevalence and incidence of forcible rape and attempted rape of females. Victimology: An International Journal, 7(1-4), 81-93. https://psycnet.apa.org/record/1984-18030-001

Sabina, C., \& Ho, L. Y. (2014). Campus and college victim responses to sexual assault and dating violence: Disclosures, service utilization, and service provision. Trauma, Violence \& Abuse, 15(3), 201-226. https://doi.org/10.1177/1524838014521322

Sable, M. R., Danis, F., Mauzy, D. L., \& Gallagher, S. K. (2006). Barriers to reporting sexual assault for women and men: Perspectives of college students. Journal of American College Health, 55(3), 157-162. https://doi.org/10.3200/JACH.55.3.157-162

Saldaña, J. (2009). The coding manual for qualitative researchers. Sage. 
Sampson, R. (2002). The problem of acquaintance rape of college students. Problem-oriented guides for police services \#17. U.S. Department of Justice. http://www.popcenter.org/problems/pdfs/Acquaintance Rape of College Students.pdf

Schwartz, Z. (2018, March 1). Canadian universities are failing students on sexual assault. Maclean's. https://www.macleans.ca/education/universityl canadian-universities-are-failing-students-on-sexual-assault/

Smith, C. P., \& Freyd, J. (2013). Dangerous safe havens: Institutional betrayal exacerbates sexual trauma. Journal of Traumatic Stress, 26, 119-124. https:II doi.org/10.1002/jts.21778

Smith, C. P., \& Freyd, J. (2014). Institutional betrayal. American Psychologist, 69(6), 575-587. https://doi. org/10.1037/a0037564

Smith, C. P., Gomez, J. M., \& Freyd, J. (2014). The psychology of judicial betrayal. Roger Williams University Law Review, 19, 451-475. https://docs.rwu.edul cgi/viewcontent.cgi?article=1539\&context=rwu LR

Statistics Canada. (2014). Cycle 28 of the Statistics Canada General Social Survey. https://www150. statcan.gc.ca/n1/en/catalogue/12M0026X

Streng, T. K., \& Kamimura, A. (2017). Perceptions of university policies to prevent sexual assault on campus among college students in the USA. Sexuality Research and Social Policy, 14, 133-142. https:/l doi.org/10.1007/s13178-016-0245-X

Strout, T., Amar, A. F., \& Astwood, K. (2014). Women's centre staff perceptions of the campus climate on sexual violence. Journal of Forensic Nursing, 10(3), 135-143. https://doi.org/10.1097/ JFN.0000000000000034

Sulkowski, M. L. (2011). An investigation of students' willingness to report threats of violence in campus communities. Psychology of Violence, 1(1), 53-65. https://doi.org/10.1037/a0021592

Suzuki, Y. E., \& Bonner, H. S. (2017). Factors associated with college students' responses to rape-disclosure scenarios: Influence of gender, rape characteristics, and opinions about health professionals. Journal of School Violence, 16(2), 160-172. https://doi.org/10.

\section{$1080 / 15388220.2017 .1284482$}

Taylor, S. C., \& Gassner, L. (2010). Stemming the flow: Challenges for policing adult sexual assault with regard to attrition rates and under-reporting of sexual offences. Police Practice and Research, 11(3), 240255. https://doi.org/10.1080/15614260902830153

United States Senate. (2014). Sexual violence on campus. How too many institutions of higher education are failing to protect students. https://docplayer. net/23779-Sexual-violence-on-campus.html

Walsh, W. A., Banyard, V. L., Moynihan, M. M., Ward, S., \& Cohn, E. S. (2010). Disclosure and service use on a college campus after an unwanted sexual experience. Journal of Trauma and Dissociation, 11(2), 134-151. https://doi. org/10.1080/15299730903502912

Ward, S., Chapman, K., Cohn, E., White, S., \& Williams, K. (1991). Acquaintance rape and the college social scene. Family Relations, 40, 65-71. https://doi. org/10.2307/585660

Williams, S. L., \& Nofziger, S. (2003). Cops and the college crowd: Young adults and perceptions of police in a college town. Journal of Crime and Justice, 26(2), 125-151. https://doi.org/10.1080/073564 $\underline{8 X .2003 .9721185}$

Zydervelt, S., Zajac, R., Kaladelfos, A., \& Westera, N. (2017). Lawyers' strategies for cross-examining rape complainants: Have we moved beyond the 1950s? The British Journal of Criminology, 57(3), 551-569. https://doi.org/10.1093/bjc/azw023

\section{Contact Information}

Olga Marques

Olga.Marques@uoit.ca

\section{Notes}

1 Students could participate in one or both components of the study. 